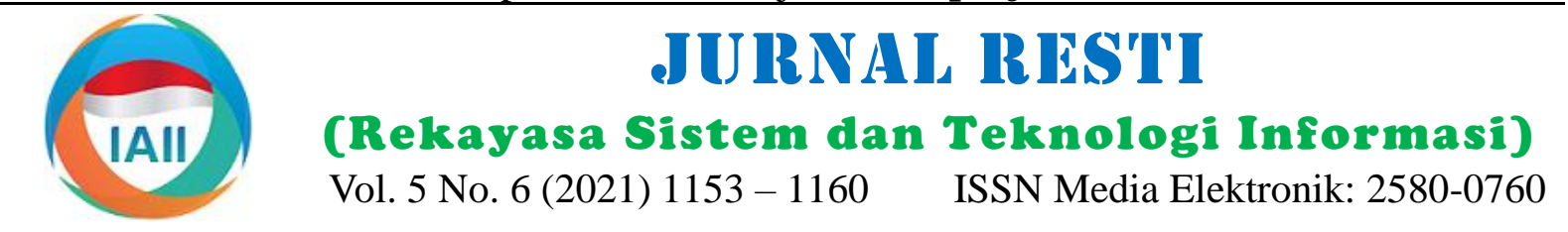

\title{
Penerapan Convolutional Neural Networks untuk Mesin Penerjemah Bahasa Daerah Minangkabau Berbasis Gambar
}

\author{
Mayanda Mega Santoni ${ }^{1}$, Nurul Chamidah ${ }^{2}$, Desta Sandya Prasvita ${ }^{3}$, Helena Nurramdhani Irmanda ${ }^{4}$, Ria \\ Astriratma $^{5}$, Reza Amarta Prayoga ${ }^{6}$ \\ 1,2,3Program Studi Informatika, Fakultas Ilmu Komputer, UPN Veteran Jakarta \\ ${ }^{4,5}$ Program Studi Sistem Informasi, Fakultas Ilmu Komputer, UPN Veteran Jakarta \\ ${ }^{6}$ Pusbanglin BPP Bahasa, Kementerian Pendidikan dan Kebudayaan \\ 1'megasantoni@upnvj.ac.id, ${ }^{2}$ nurul.chamidah@upnvj.ac.id, ${ }^{3}$ desta.sandya@upnvj.ac.id, ${ }^{4}$ helenairmanda@upnvj.ac.id, \\ 5astriratma@upnvj.ac.id, ${ }^{6}$ reza.amarta@kemdikbud.go.id
}

\begin{abstract}
One of efforts by the Indonesian people to defend the country is to preserve and to maintain the regional languages. The current era of modernity makes the regional language image become old-fashioned, so that most them are no longer spoken. If it is ignored, then there will be a cultural identity crisis that causes regional languages to be vulnerable to extinction. Technological developments can be used as a way to preserve regional languages. Digital image-based artificial intelligence technology using machine learning methods such as machine translation can be used to answer the problems. This research will use Deep Learning method, namely Convolutional Neural Networks (CNN). Data of this research were 1300 alphabetic images, 5000 text images and 200 vocabularies of Minangkabau regional language. Alphabetic image data is used for the formation of the CNN classification model. This model is used for text image recognition, the results of which will be translated into regional languages. The accuracy of the CNN model is $98.97 \%$, while the accuracy for text image recognition (OCR) is 50.72\%. This low accuracy is due to the failure of segmentation on the letters $i$ and $j$. However, the translation accuracy increases after the implementation of the Leveinstan Distance algorithm which can correct text classification errors, with an accuracy value of 75.78\%. Therefore, this research has succeeded in implementing the Convolutional Neural Networks (CNN) method in identifying text in text images and the Leveinstan Distance method in translating Indonesian text into regional language texts.
\end{abstract}

Keywords: Convolutional Neural Networks, Translation, Indonesia Language, Local Language Minangkabau, Optical Character Recognition (OCR)

\begin{abstract}
Abstrak
Salah satu upaya bela negara yang dapat dilakukan oleh masyarakat Indonesia yaitu melestarikan dan memertahankan bahasa daerah. Kemajuan zaman membuat penggunaan bahasa daerah dianggap kuno dan ketinggalan zaman, sehingga kebanyakan bahasa daerah tidak dituturkan oleh penuturnya lagi. Jika hal tersebut diabaikan, maka akan terjadi krisis identitas budaya yang menyebabkan bahasa daerah rawan punah. Perkembangan teknologi dapat dimanfaatkan sebagai upaya melestarikan bahasa daerah. Teknologi kecerdasan buatan berbasis citra digital menggunakan metode machine learning seperti mesin penerjemah, dapat dimanfaatkan untuk menjawab permasalahan tersebut. Pada penelitian ini akan menggunakan metode Deep Learning, yakni Convolutional Neural Networks (CNN). Data penelitian yang digunakan sebanyak 1300 citra alfabet, 5000 citra teks dan 200 kosa kata dari bahasa daerah Minangkabau. Data citra alfabet digunakan untuk pembentukan model klasifikasi CNN. Model ini digunakan untuk pengenalan citra teks yang hasilnya akan dilakukan penerjemahan ke bahasa daerah. Akurasi model CNN diperoleh sebesar 98.97\%, sedangkan akurasi untuk pengenalan citra teks (Optical Character Recognition - OCR) sebesar $50.72 \%$. Akurasi ini rendah disebabkan karena terdapatnya kegagalan segmentasi pada huruf i dan j. Namun akurasi terjemahan meningkat setelah diterapkannya algoritma Leveinstan Distance yang dapat memperbaiki kesalahan klasifikasi teks, dengan nilai akurasi sebesar $75.78 \%$. Oleh karena itu pada penelitian ini telah berhasil mengimplementasikan metode Convolutional Neural Networks (CNN) dalam mengidentikasi teks pada citra teks dan metode Leveinstan Distance dalam menerjemahkan teks bahasa indonesia ke dalam teks bahasa daerah.
\end{abstract}

Kata kunci: Convolutional Neural Networks, Penerjemahan, Bahasa Indonesia, Bahasa Daerah Minangkabau, Optical Character Recognition (OCR)

Diterima Redaksi: 10-11-2021 | Selesai Revisi: 09-12-2021 | Diterbitkan Online: 30-12-2021 


\section{Pendahuluan}

Indonesia dikenal dunia sebagai negara dengan masyarakat majemuk, yakni masyarakat yang memiliki keanekaragaman suku, budaya, bahasa, dan agama. Setiap suku memiliki bahasa sendiri yang biasa disebut sebagai bahasa daerah. Bahasa daerah merupakan salah satu unsur penting dari keberlanjutan lestarinya suatu suku. Jika bahasa daerah terus dilestarikan maka transmisi bahasa daerah akan kekal diwariskan ke
generasi-generasi berikutnya. Berdasarkan data yang dikeluarkan oleh Badan Pengembangan dan Pembinaan

Bahasa, Kementerian Pendidikan dan Kebudayaan, Indonesia memiliki 718 bahasa daerah yang tersebar dari Sabang sampai Merauke [1]. Bahkan National Geographic memprediksi dari sekitar 7000 bahasa ibu yang ada saat ini akan punah pada akhir abad ini [2].

Salah satu bahasa daerah yang ada di Indonesia adalah bahasa Minang. Bahasa minang merupakan bahasa daerah dari suku Minangkabau yang berakar kuat dari daerah Sumatera Barat. Kelestarian bahasa Minangkabau sangat ditentukan oleh sikap penuturnya menerima inputan dari pengguna berupa citra digital [3]. Proyeksi dari temuannya kedepan bahasa yang memiliki teks Bahasa Indonesia. Selanjutnya Minangkabau secara perjalanan waktu mengalami mesin penerjemah akan menampilkan terjemahan pelapukan. Hal ini disebabkan terjadinya pergeseran bahasa daerahnya sesuai dengan bahasa daerah yang penutur khususnya di perkotaan khususnya kalangan pengguna tentukan di awal. Pemilihan data citra digital remaja dan keluarga muda cenderung meninggalkan dimaksud untuk memudahkan pengguna dalam penggunaan Bahasa Minangkabau dalam komunikasi menerjemahkan bahasa tanpa harus mengetikkan katasehari-hari. Bahasa Indonesia dan Bahasa Asing kata yang ingin diterjemahkan [6].

terutama Bahasa Inggris menjadi penggeropos bahasa Minangkabau karena terinterferensi dari bahasa Indonesia dan bahasa asing (Inggris). Jika proyeksi ini senyatanya terjadi, maka tidak dapat dihindarkan lagi bahasa Minangkabau di ranah Minang akan mengalami kekaburan identitas bahasa di kalangan remaja dan keluarga muda. Langkah yang tepat perlu diambil untuk mendokumentasikan dan mengalihwahanakan bahasa Minangkabau dengan bantuan teknologi sangat berperan penting.

Di era teknologi 4.0 saat ini memengaruhi perubahan 作 gaya hidup dan gaya berkomunikasi masyarakat. dengan teks yang banyak untuk diterjemahkan, maka Penggunaan bahasa daerah dianggap sebagai gaya akan sangat menyulitkan pengguna. Maka dari itu, komunikasi yang tertinggal, kolot, dan kampungan, penelitian ini mencoba menyempurnakan penelitian sehingga generasi milenial saat ini banyak sebelumnya dengan lebih memperkuat implementasi meninggalkan dan tidak peduli terhadap basis citra digital dalam penerjemahan Bahasa Indonesia keberlangsungan bahasa daerah. Menurut temuan ke Bahasa Daerah. Lebih lanjut, penerjemahanan bahasa Prayoga dan Khatimah [4], ketidakpedulian ini berasal Indonesia ke Bahasa daerah dengan implementasi basis dari keterniatan masyarakat Indonesia sendiri yang citra digital diharapkan mampu mempermudah akses menganggap dan meletakkan bahasa daerah sebagai pengguna dalam penerjemahan dalam jumlah teks yang pilihan yang tidak rasional dalam menghadapi era banyak. Penerjemahan berbasis citra digital yang sudah kompetisi global. Maka dari itu, penetrasi bahasa asing dilakukan untuk menerjemahkan Bahasa Indonesia ke menjadi ancaman terhadap eksistensi bahasa daerah, Bahasa Inggris atau sebaliknya [6, 11]. Sementara itu karena tidak lagi menjadi pilihan utama dalam berbagai untuk Bahasa Indonesia ke Bahasa Daerah telah ranah baik Pendidikan, Ekonomi, dan Pemerintahan. dilakukan untuk Aksara Lampung [5]. Oleh karena itu, Generasi milenial lebih pragmatis yakni memilih untuk penerjemahan Bahasa berbasis citra digital/gambar berbahasa asing agar mereka dapat diterima di masih perlu dilakukan. 
Salah satu metode machine learning yang saat ini sedang performa sekitar $90 \%$ sampai dengan $99.8 \%$. menjadi topik hangat di kalangan peneliti yakni metode Phangtriastu et.al [14] juga melakukan penelitian OCR Deep Learning. Deep Learning adalah perkembangan untuk membandingkan metode Neural Networks dan dari metode Neural Networks untuk menyelesaikan Support Vector Machine. Akurasi tertinggi untuk berbagai permasalahan. Salah satu metode deep learning masing-masing metode yakni Neural Networks sebesar yang digunakan untuk mengklasifikasikan data gambar 93.48\%, sedangkan Support Vector Machine sebesar yakni Convolutional Neural Networks (CNN). Banyak 94.43\%. Srivastava et.al [15] juga melakukan permasalahan klasifikasi gambar berhasil diselesaikan identifikasi karakter optik pada dokumen cek Bank dengan menggunakan metode CNN. Teknik CNN menggunakan 2D Convolutional Neural Networks menggunakan high level feature yang mana fitur yang dengan performa akurasi sebesar 95.71\%. Bhunia et.al ada pada gambar tidak perlu didefinisikan secara [16] juga melakukan penelitian untuk mengidentikasi spesifik (handcrafted features) karena di dalam CNN tulisan pada data citra pemandangan (natural scene terdapat lapisan yang disebut feature extraction layer image) menggunakan Convolutional-LSTM Network [12].

yang menghasilkan akurasi tertinggi pada dataset MLe2e sebesar 96.70\%. Wang,et.al [17] melakukan

Berdasarkan permasalahan yang ada dan penelitianpenelitian sebelumnya yang telah dibahas, maka penelitian ini ini akan menerapkan Convolutional Neural Networks untuk mengklasifikasikan teks pada citra/gambar untuk diterjemahkan dari Bahasa Indonesia Berdasarkan penelitian penulis sebelumnya [18], ke Bahasa Daerah Minangkabau. Algoritma Leveinstan Algoritma Leveinstan Distance merupakan algoritma Distance digunakan untuk penerjemahan Bahasa yang paling memberikan akurasi yang paling baik dalam Indonesia ke Bahasa Daerah Minangkabau.

\section{Metode Penelitian}

Tahapan penelitian meliputi beberapa tahapan, yaitu studi literatur, pengumpulan data, pembentukan model klasifikasi OCR CNN dan evaluasi model klasifikasi. Gambaran umum tahapan penelitian dapat dilihat pada Gambar 1

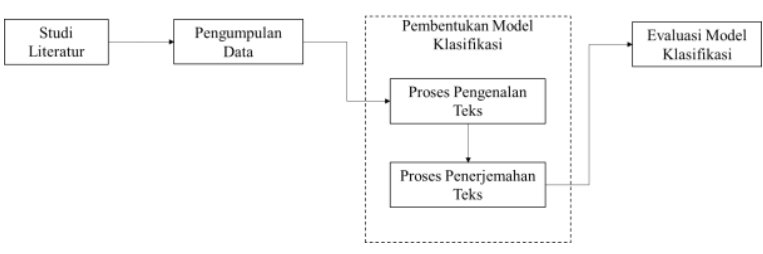

Gambar 1. Tahapan Penelitian

\subsection{Studi Literatur}

Pada tahapan awal penelitian, Penulis mengumpulkan informasi, landasan teori serta hasil pada penelitian sebelumnya yang relevan terkait dengan penelitian yang akan dilakukan. Tahapan ini sangat penting karena akan memperkaya pengetahuan dan landasan teori mengenai penelitian yang akan dilakukan serta untuk mengetahui state of the art penelitian Convolutional Neural Networks pada proses pengenalan dan klasifikasi citra khusunya pada citra yang mengandung teks.

Penelitian kecerdasan buatan untuk identifikasi teks pada data citra digital sudah banyak dilakukan. Pada penelitian Naseer dan Zafar [13] melakukan analisis komparatif antara metode CNN dan LSTM dalam Samsung mengidentifikasi karakter (OCR - Optical Character Galaxy J5 (D2) Recognition) dengan font ligatures pada bahasa Urdu yang merupakan bahasa nasional Pakistan dengan identifikasi pada CAPTCHA menggunakan

Convolutional Neural Networks dengan akurasi tertinggi $98.96 \%$. pemrosesan data teks khususnya pada mesin penerjemahan Bahasa Indonesia ke Bahasa daerah Minangkabau. Selain itu, Hossain, et.al [19] menggunakan Leveinstan Distance dalam melakukan perbaikan otomatis pada hasil terjemahan Bahasa Bengali ke Bahasa Inggris dengan tingkat akurasi sebesar 78.13\%. Penelitian Wint, Ducros, dan Aritsugi [20] menggunakan Leveinstan Distance untuk melalukan perbaikan ejaan pada dataset sosial media dengan tingkat akurasi 90\%. Yulianto, Arifudin, dan Alamsyah [21] juga menggunakan Leveinstan Distance untuk melakukan autocomplete dan spell checking dalam proses pencarian data perpustakaan.

\subsection{Pengumpulan Data}

Data citra yang digunakan pada penelitian ini adalah data citra yang mengandung teks cetak (printed text). Data penelitian akan dibagi menjadi tiga kelompok data. Pertama, data citra alfabet/karakter/huruf baik itu huruf kecil dan kapital dengan menggunakan lima jenis font berbeda yaitu Times New Roman, Calibri, Arial, Bodoni, dan Helvetica dan lima jenis device/perangkat yang berbeda yakni Scanner, Samsung Galaxy J5, Iphone 4, Iphone 5s, dan Iphone 7. Spesifikasi dari setiap device dapat dilihat pada Tabel 1.

Tabel 1. Spesifikasi device/perangkat pengambilan citra

\begin{tabular}{|c|c|c|c|}
\hline $\begin{array}{l}\text { Jenis Perangkat } \\
\text { (Kode) }\end{array}$ & $\begin{array}{l}\text { Megapixel/ } \\
\text { Scanner Type }\end{array}$ & $\begin{array}{l}\text { Bukaan (f/)/ } \\
\text { Sensor } \\
\text { Type }\end{array}$ & $\begin{array}{l}\text { Ukuran piksel / } \\
\text { Optical } \\
\text { Resolution }\end{array}$ \\
\hline $\begin{array}{l}\text { Scanner } \\
\text { EPSON (D1) }\end{array}$ & $600 \times 1200 \mathrm{dpi}$ & CIS & $\begin{array}{l}\text { Flatbed Colour } \\
\text { Image Scanner }\end{array}$ \\
\hline $\begin{array}{l}\text { Samsung } \\
\text { Galaxy J5 (D2) }\end{array}$ & $13 \mathrm{MP}$ & $\mathrm{f} / 1.9$ & $1.15 \mu \mathrm{m}$ \\
\hline Iphone 4 (D3) & $15 \mathrm{MP}$ & $\mathrm{f} / 2.8$ & $1.5 \mu \mathrm{m}$ \\
\hline Iphone 5S (D4) & $8 \mathrm{MP}$ & $\mathrm{f} / 2.2$ & $1.5 \mu \mathrm{m}$ \\
\hline Iphone 7 (D5) & $12 \mathrm{MP}$ & $\mathrm{f} / 1.8$ & $1.22 \mu \mathrm{m}$ \\
\hline
\end{tabular}


Data citra ini nantinya akan digunakan untuk proses citra. Hasil segmentasi berupa kumpulan karakter pembentukan model identifikasi karakter dengan alfabet dari kata teks yang terdapat pada citra menggunakan metode CNN. Kedua, selain data citra sebelumnya. Selanjutnya setiap karakter tersebut, alfabet, terdapat juga data citra teks yang terdiri dari kata diujikan ke dalam model pelatihan CNN yang diperoleh (bukan kalimat) yang nantinya akan diujikan ke model dari tahapan pelatihan. Hasil identifikasi atau klasifikasi CNN yang telah dihasilkan sebelumnya. Ketiga, data karakter digabungkan kembali untuk membentuk kata. kamus bahasa Indonesia beserta artinya dalam bahasa Kata ini nanti akan digunakan untuk diterjemahkan ke daerah Minangkabau.

\subsection{Pembentukan Model Klasifikasi CNN}

Setelah data penelitian diperoleh, selanjutnya dilakukan perancangan metode penelitian. Pada tahapan ini, akan ditentukan constraint penelitian, seperti jumlah data, ukuran gambar dan arsitektur penelitian yang akan digunakan. Setelah itu akan dirancang tahapan implementasi dari metode penelitian yang diusulkan tersebut, sehingga diperoleh hasil pengenalan karakter tulisan print yang terdapat dalam sebuah citra digital. Gambaran umum rancangan metode penelitian dapat dilihat pada Gambar 2.

dalam bahasa daerah.

Teks yang dihasilkan dari proses pengenalan teks di atas, akan digunakan untuk proses penerjemahan ke dalam bahasa daerah. Proses penerjemahan dilakukan menggunakan algoritma Levenshtein Distance dengan cara mengukur jumlah transformasi teks yang diperlukan untuk mengubah teks hasil pengenalan ke teks yang terdapat dalam kamus. Jumlah transformasi terkecil yang akan dipilih sebagai hasil terjemahan.

\subsection{Evaluasi Model Klasifikasi}

Evaluasi dan analisis hasil dilakukan untuk mengetahui pengaruh metode yang diusulkan terhadap hasil akurasi Proses pengenalan teks bahasa indonesia pada sebuah pengenalan karakter teks tercetak pada citra. Hasil yang citra digital dilakukan melalui dua tahapan. Tahapan diperoleh pada penelitian ini akan diujikan apakah pertama adalah tahapan pelatihan (training) yang identifikasi yang dihasilkan akurat sesuai dengan dilakukan untuk mendapatkan model CNN yang dapat groundtruth. Groundtruth merupakan label kelas yang mengenali masing-masing karakter alfabet. Data telah diketahui sebelumnya. Pengujian yang akan masukan yang digunakan pada tahapan ini adalah data dilakukan dengan menggunakan nilai akurasi. Terdapat citra karakter alfabet huruf kecil dan kapital dari lima tiga nilai akurasi yang akan diperoleh pada penelitian jenis font yang berbeda. Selanjutnya data tersebut ini. Pertama adalah nilai akurasi dari metode CNN digunakan untuk pelatihan dengan menggunakan dalam mengklasifikasikan karakter tercetak pada citra metode CNN, sehingga diperoleh model pelatihan CNN. (Optical Character Recognition). Nilai evaluasi kedua

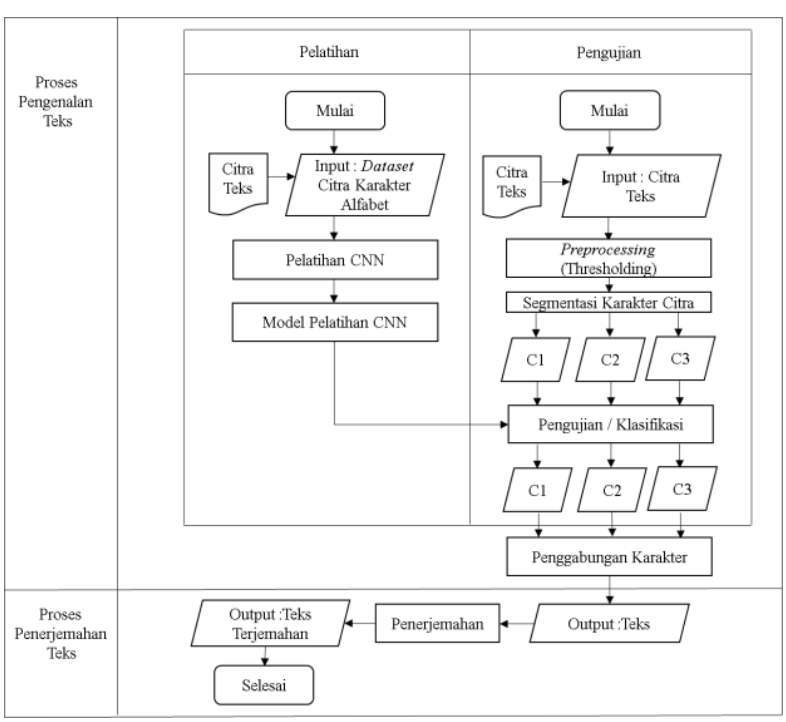

Gambar 2. Perancangan Eksperimen Penelitian

Tahapan kedua adalah tahapan pengujian (testing) yang dilakukan untuk menguji performa model CNN yang telah diperoleh dari tahapan pelatihan. Pada tahapan ini, data masukan berupa data citra teks yang berisikan kata (bukan kalimat) Bahasa Indonesia. Sebelum dilakukan segmentasi, terlebih dahulu dilakukan praproses data yakni nilai akurasi klasifikasi kata pada citra teks. Nilai evaluasi ini digunakan untuk mengetahui performa dari model CNN yang diperoleh pada evaluasi sebelumnya untuk mengklasifikasikan kata pada citra teks. Nilai evaluasi ketiga yakni nilai akurasi terjemahan. Nilai evaluasi ini digunakan untuk mengetahui performa dari metode Levenshtein Distance dalam menerjemahkan hasil klasifikasi kata pada citra teks.

\section{Hasil dan Pembahasan}

\subsection{Dataset}

Pada penelitian ini, menggunakan tiga kelompok data. Pertama, citra alfabet yang terdiri dari 26 alfabet baik huruf kecil dan kapital. Data ini digunakan sebagai citra masukkan pada pelatihan model CNN dalam melakukan klasifikasi karakter tercetak pada citra (Optical Character Recognition). Masing-masing alfabet memiliki 25 citra yang diperoleh dari pengambilan citra pada 5 device dan 5 jenis font, sehingga total citra pada data ini sebanyak 5 device $\mathrm{x} 5$ font $\mathrm{x} 26$ alfabet $\mathrm{x}$ (huruf kecil dan huruf kapital) $=1300$ citra.

Kedua, citra teks yang terdiri dari 200 kata yang berasal dari daftar kata swadesh. Daftar kata ini kami peroleh dari Laboratorium Kebinekaan Bahasa dan Sastra, Kementerian Pendidikan dan Kebudayaan. Masing- 
masing kata dilakukan pengambilan gambar pada 5 Nilai akurasi menunjukkan tingkat kebenaran metode device dan 5 jenis font, sehingga total citra pada data ini CNN dalam melakukan klasifikasi alfabet sangat baik. sebanyak 200 kata x 5 device x 5 font $=5000$ citra. Nilai akurasi, precion dan recall tiap alfabet dapat Ketiga, kamus bahasa daerah yakni Bahasa dilihat pada Tabel 2.

Minangkabau dari 200 kata pada daftar kata swadesh yang diurutkan berdasarkan Bahasa Indonesianya dari huruf A ke Z.

\subsection{Hasil Eksperimen dan Evaluasi}

Pada penelitian ini, terdapat tiga eksperimen yang akan dievaluasi. Pertama adalah performa metode $\mathrm{CNN}$ dalam melakukan klasifikasi citra alfabet tercetak (Optical Character Recognition). Nilai akurasi terbaik pada eksperimen ini adalah sebesar 98.97\%. Nilai hyperparameter terbaik yang digunakan pada model yaitu epoch sebanyak 200, nilai batch size sebesar 50 dan nilai learning rate sebesar 0,001 .
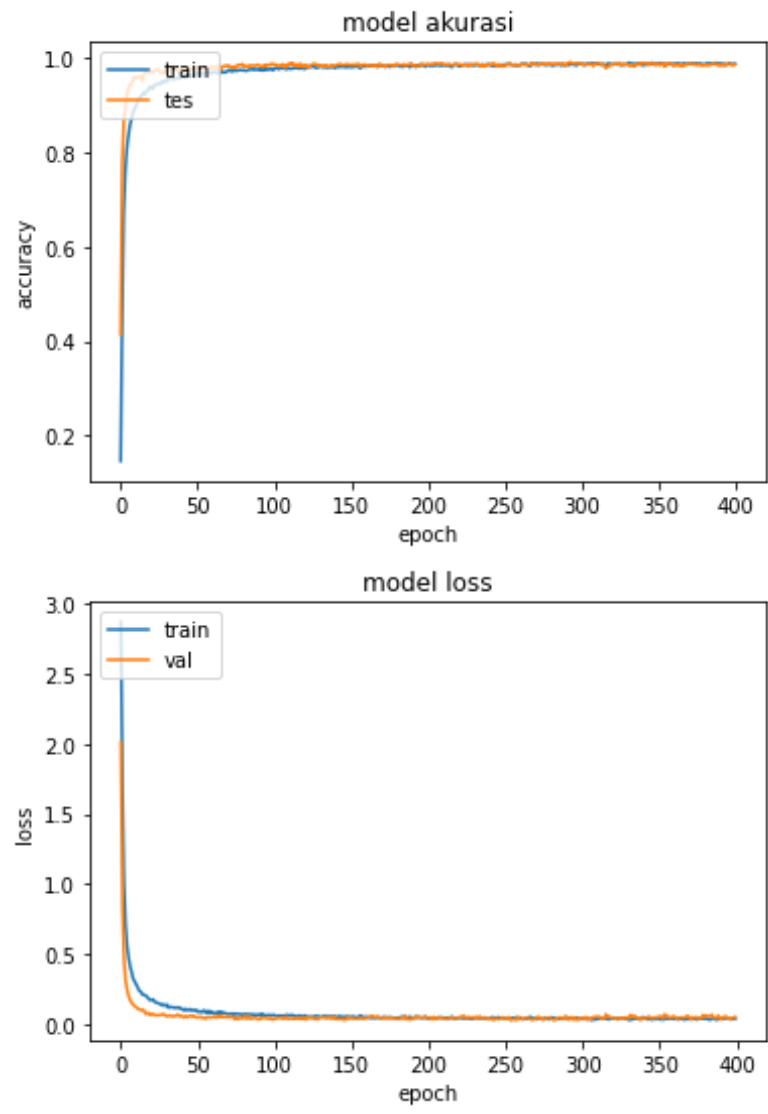

Gambar 3. Hasil plot model akurasi dan loss function

Gambar 3 menampilkan grafik proses model akurasi dan model loss untuk proses training dan testing. Pada proses training dan testing dapat dilihat bahwa dengan bertambahnya epoch, secara umum akurasinya juga meningkat, berkorelasi dengan loss yang semakin menurun. Hal ini menunjukkan model dapat belajar dengan baik berdasarkan data training dan testing yang diberikan.

\begin{tabular}{|c|c|c|c|}
\hline Huruf & Akurasi & Precision & Recall \\
\hline A & 1.000 & 1.00 & 1.00 \\
\hline B & 1.000 & 1.000 & 1.000 \\
\hline $\mathrm{C}$ & 1.000 & 1.000 & 1.000 \\
\hline D & 1.000 & 1.000 & 1.000 \\
\hline E & 1.000 & 1.000 & 1.000 \\
\hline $\mathrm{F}$ & 0.978 & 1.000 & 0.978 \\
\hline G & 1.000 & 1.000 & 1.000 \\
\hline $\mathrm{H}$ & 1.000 & 1.000 & 1.000 \\
\hline I & 0.888 & 0.888 & 0.888 \\
\hline $\mathrm{J}$ & 1.000 & 1.000 & 1.000 \\
\hline K & 1.000 & 1.000 & 1.000 \\
\hline $\mathrm{L}$ & 1.000 & 0.891 & 0.911 \\
\hline M & 1.000 & 1.000 & 1.000 \\
\hline $\mathrm{N}$ & 1.000 & 1.000 & 1.000 \\
\hline $\mathrm{O}$ & 1.000 & 1.000 & 1.000 \\
\hline $\mathrm{P}$ & 1.000 & 1.000 & 1.000 \\
\hline $\mathrm{Q}$ & 1.000 & 1.000 & 1.000 \\
\hline $\mathrm{R}$ & 1.000 & 0.978 & 1.000 \\
\hline $\mathrm{S}$ & 1.000 & 1.000 & 1.000 \\
\hline $\mathrm{T}$ & 0.978 & 1.000 & 0.978 \\
\hline U & 1.000 & 1.000 & 1.000 \\
\hline V & 0.978 & 1.000 & 0.978 \\
\hline W & 1.000 & 1.000 & 1.000 \\
\hline$X$ & 1.000 & 1.000 & 1.000 \\
\hline Y & 1.000 & 0.978 & 1.000 \\
\hline Z & 1.000 & 1.000 & 1.000 \\
\hline A & 1.000 & 1.00 & 1.00 \\
\hline B & 1.000 & 1.000 & 1.000 \\
\hline $\mathrm{C}$ & 1.000 & 1.000 & 1.000 \\
\hline D & 1.000 & 1.000 & 1.000 \\
\hline E & 1.000 & 1.000 & 1.000 \\
\hline $\mathrm{F}$ & 0.978 & 1.000 & 0.978 \\
\hline G & 1.000 & 1.000 & 1.000 \\
\hline $\mathrm{H}$ & 1.000 & 1.000 & 1.000 \\
\hline I & 0.888 & 0.888 & 0.888 \\
\hline $\mathrm{J}$ & 1.000 & 1.000 & 1.000 \\
\hline $\mathrm{K}$ & 1.000 & 1.000 & 1.000 \\
\hline $\mathrm{L}$ & 1.000 & 0.891 & 0.911 \\
\hline M & 1.000 & 1.000 & 1.000 \\
\hline $\mathrm{N}$ & 1.000 & 1.000 & 1.000 \\
\hline $\mathrm{O}$ & 1.000 & 1.000 & 1.000 \\
\hline $\mathrm{P}$ & 1.000 & 1.000 & 1.000 \\
\hline Q & 1.000 & 1.000 & 1.000 \\
\hline $\mathrm{R}$ & 1.000 & 0.978 & 1.000 \\
\hline S & 1.000 & 1.000 & 1.000 \\
\hline $\mathrm{T}$ & 0.978 & 1.000 & 0.978 \\
\hline $\mathrm{U}$ & 1.000 & 1.000 & 1.000 \\
\hline V & 0.978 & 1.000 & 0.978 \\
\hline W & 1.000 & 1.000 & 1.000 \\
\hline $\mathrm{X}$ & 1.000 & 1.000 & 1.000 \\
\hline $\mathrm{Y}$ & 1.000 & 0.978 & 1.000 \\
\hline $\mathrm{Z}$ & 1.000 & 1.000 & 1.000 \\
\hline \multicolumn{4}{|c|}{$\begin{array}{l}\text { Diperoleh hasil bahwa mayoritas kelas dapat } \\
\text { diklasifikan dengan sempurna yang ditunjukkan dengan } \\
\text { nilai akurasi, precision dan recall sama dengan } 1.00 \text {. } \\
\text { Dari } 26 \text { alfabet yang ada, huruf i dan } 1 \text { memiliki nilai } \\
\text { precision yang paling rendah yakni } 0.89 \text {. Tingkat } \\
\text { precision menunjukkan tingkat kebenaran prediksi kelas } \\
\text { terhadap keseluruhan data yang diprediksi sebagai kelas } \\
\text { tersebut. }\end{array}$} \\
\hline
\end{tabular}

DOI: https://doi.org/10.29207/resti.v5i6.3614

Lisensi: Creative Commons Attribution 4.0 International (CC BY 4.0) 
Dilihat dari confussion matrix pada Gambar 4, jumlah sebenarnya yakni justru diprediksi sebagai data kelas data yang terklasifikasikan benar adalah huruf i (true lain.

positive) sebanyak 40 data, sedangkan jumlah kelas yang terprediksi sebagai huruf i (false positive) sebanyak 45 data. Oleh karena itu precision dari huruf i adalah 40/45 $=0.888$. Hal ini menunjukkan masih terdapat 5 data yang terklasifikasikan salah sebagai kelas I (false positive). Begitu juga dengan huruf 1 , jumlah data yang terklasifikasikan benar adalah huruf 1 (true positive) sebanyak 41 data. Sementara itu, jumlah kelas yang terprediksi sebagai huruf 1 sebanyak 46 data, sehingga precision dari huruf 1 adalah $41 / 46=0.891$.

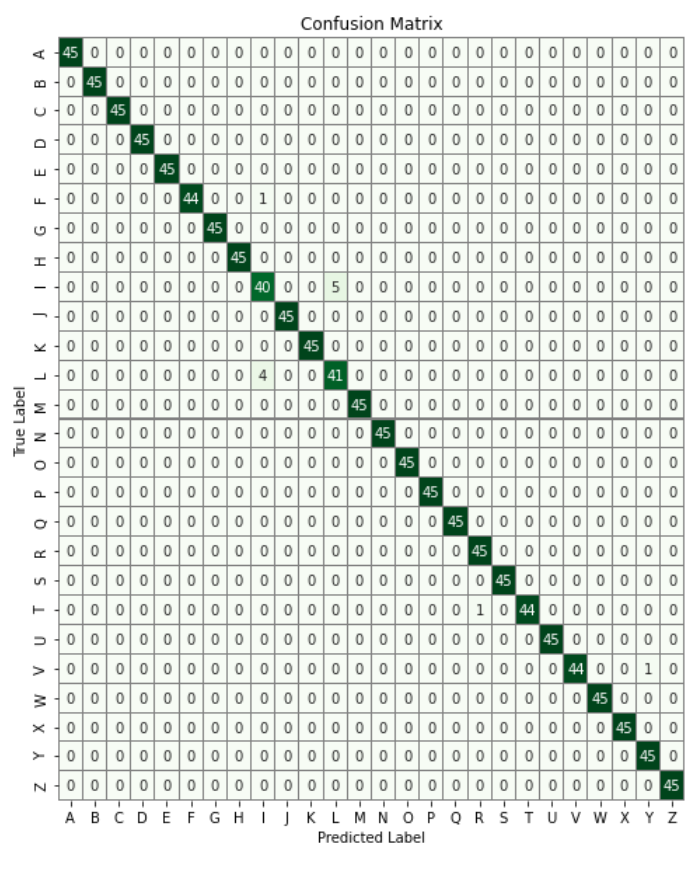

Gambar 4. Confusion Matrix Model OCR CNN

Huruf i juga memiliki nilai recall paling rendah yakni 0.89 . Tingkat recall menunjukkan tingkat kebenaran prediksi kelas terhadap keseluruhan data yang sebenarnya kelas tersebut. Pada huruf i jumlah data yang terklasifikasi benar adalah huruf i (true positive) sebanyak 40 data, sedangkan jumlah data yang sebenarnya kelas huruf i sebanyak 45 data, sehingga nilai recall dari huruf I adalah 40/45 $=0.888$. Berbeda dengan huruf 1 , nilai recall pada huruf 1 adalah 0.91 , yang mana jumlah data yang terklasifikasikan benar kata dari masing-masing device dan font dapat dilihat adalah huruf 1 (true positive) sebanyak 41 data dan pada Tabel 3. Dalam tabel akurasi klasifikasi kata ini, sedangkan jumlah data yang sebenarnya kelas huruf 1 dapat dilihat bahwa akurasi tertinggi diperoleh dari data sebanyak 45 data. Pada huruf 1, nilai precision lebih citra teks dengan jenis font 1 (Arial) dan font 4 rendah dibandingkan nilai recall. Hal ini menunjukkan (Helvetica) menggunakan device 5 (iPhone 7), yaitu bahwa masih terdapat data yang sebenarnya bukan huruf sebesar 58,0\%. Selain itu, akurasi terendah diperoleh 1 namun diprediksi sebagai huruf 1 (false positive). dari data citra teks dengan jenis font 2 (Bodoni) dengan Sementara itu, untuk huruf f, $\mathrm{t}$ dan v memiliki nilai menggunakan device 3 (iPhone 4), yaitu sebesar 0,5\%. precision yang lebih tinggi daripada nilai recall. Hal ini menunjukkan bahwa masih terdapat kejadian false negative, yakni kesalahan prediksi pada data kelas yang
Eksperimen kedua yang akan dievaluasi adalah hasil klasifikasi kata pada citra teks menggunakan model OCR CNN yang telah dievaluasi sebelumnya. Contoh hasil klasifikasi kata pada citra teks dapat dilihat pada Gambar 5.

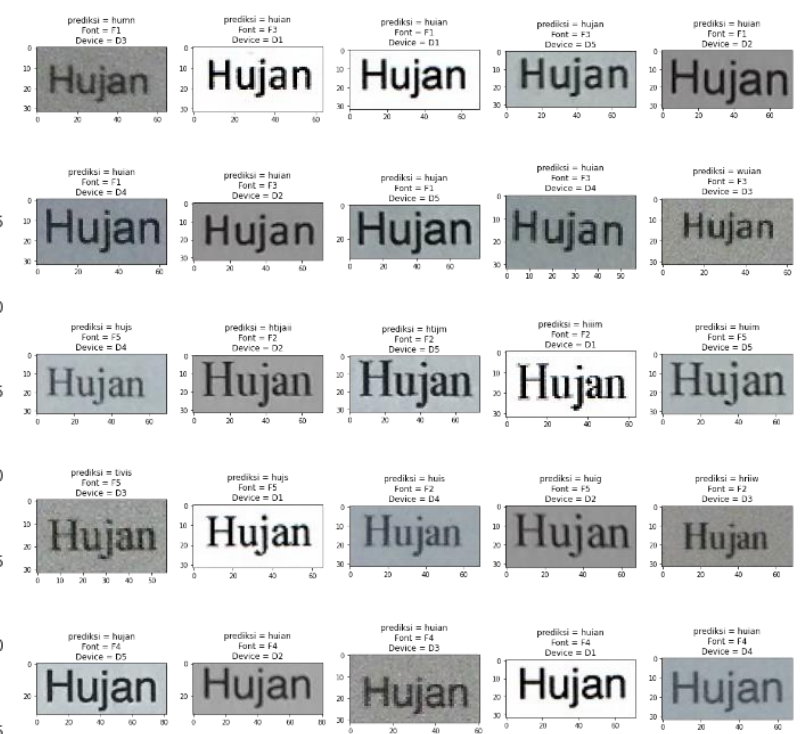

Gambar 5. Contoh hasil klasifikasi kata pada citra teks

Dapat dilihat gambar tersebut, masih banyak terjadi kesalahan klasifikasi. Kesalahan sering terjadi diakibatkan kegagalan dalam melakukan segmentasi objek khususnya untuk huruf i dan j. Karena dua huruf ini akan tersegmentasi menjadi 2 objek yang berbeda, yakni huruf i serta tanda titiknya. Contoh kegagalan segmentasi dapat dilihat pada Gambar 6.

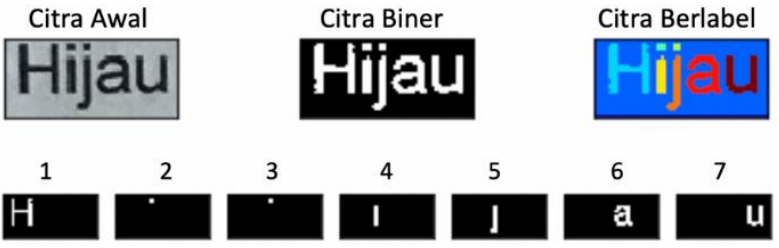

Gambar 6. Kesalahan Pelabelan Objek bukan Huruf

Eksperimen ketiga yang akan dievaluasi adalah hasil penerjemahan klasifikasi kata pada citra teks yang akan diterjemahkan dari Bahasa Indonesia ke Bahasa Daerah menggunakan algoritma Leveinstan Distance.

DOI: https://doi.org/10.29207/resti.v5i6.3614

Lisensi: Creative Commons Attribution 4.0 International (CC BY 4.0) 
Tabel 3. Akurasi Klasifikasi Kata Berdasarkan Device dan Font

\begin{tabular}{crrrrc}
\hline Font/Device & \multicolumn{5}{c}{ Akurasi (\%) } \\
\cline { 2 - 6 } & D1 & \multicolumn{1}{c}{ D2 } & \multicolumn{1}{c}{ D3 } & \multicolumn{1}{c}{ D4 } & D5 \\
\hline F1 & 85.0 & 81.0 & 25.0 & 82.5 & 96.0 \\
F2 & 13.0 & 5.0 & 1.0 & 7.5 & 17.5 \\
F3 & 50.5 & 80.0 & 4.0 & 48.0 & 89.5 \\
F4 & 85.5 & 88.5 & 46.0 & 85.5 & 96.0 \\
F5 & 43.5 & 45.5 & 4.5 & 39.5 & 48.0 \\
\hline
\end{tabular}

Perhitungan akurasi keberhasilan pada proses penerjemahan dari masing-masing device dan font dapat dilihat pada Tabel 4. Dalam tabel akurasi penerjemahan ini, dapat dilihat bahwa akurasi mengalami peningkatan. Akurasi penerjemahan tertinggi diperoleh dari data citra teks dengan jenis font 1 (Arial) dan font 4 (Helvetica) dengan menggunakan device 1 (Scanner), jenis font 3 (Calibri) dengan device 2 (Samsung Galaxy J5) dan jenis font 1 (Arial) dengan device 4 (iPhone 5s) yaitu sebesar $99,5 \%$.

Tabel 4. Akurasi Terjemahan Berdasarkan Device dan Font

\begin{tabular}{cccccc}
\hline Font/Device & \multicolumn{5}{c}{ Akurasi (\%) } \\
\cline { 2 - 6 } & D1 & D2 & D3 & D4 & D5 \\
\hline F1 & 95.5 & 95.0 & 73.0 & 99.5 & 98.5 \\
F2 & 47.5 & 24.0 & 10.0 & 34.0 & 42.0 \\
F3 & 97.5 & 99.5 & 52.5 & 95.0 & 98.0 \\
F4 & 99.5 & 98.0 & 85.5 & 99.0 & 98.5 \\
F5 & 80.0 & 77.0 & 42.5 & 77.5 & 71.5 \\
\hline
\end{tabular}

Dari perhitungan akurasi di atas, dapat dilihat bahwa hasil akurasi mengalami peningkatan pada saat proses penerjemahan. Rangkuman hasil evaluasi dari semua eksperimen yang telah dilakukan dapat dilihat pada Gambar 7. Akurasi dari model CNN sebesar $98.97 \%$, kemudian mengalami penurunan pada proses klasifikasi kata (OCR) menjadi $50.72 \%$. Penurunan ini terjadi karena banyaknya kesalahan dalam melakukan segmentasi, sehingga mempengaruhi performa model OCR CNN dalam melakukan klasifikasi kata pada citra teks. Namun penurunan akurasi ini, dapat ditingkatkan dengan metode Leveinstan Distance pada tahap penerjemahan dengan akurasi terjemahan sebesar $75.78 \%$.

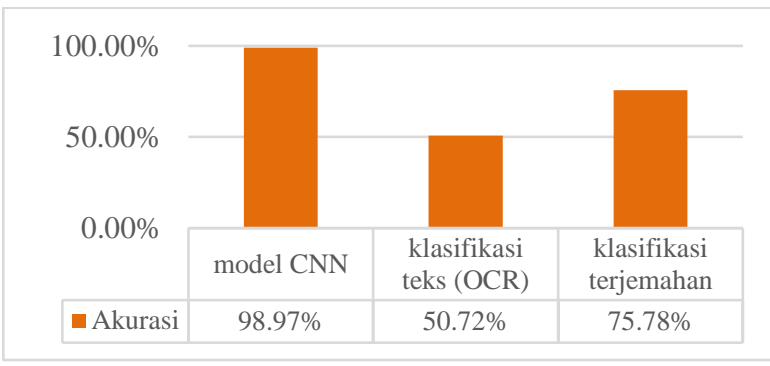

Gambar 7. Grafik Perbandingan Hasil Evaluasi Seluruh Eksperimen

\section{Kesimpulan}

Penelitian ini telah berhasil mengimplementasikan metode Convolutional Neural Networks (CNN) dalam mengidentikasi teks pada citra teks dan metode Leveinstan Distance dalam menerjemahkan teks bahasa indonesia ke dalam teks bahasa daerah. Hasil penelitian dievaluasi menggunakan tiga nilai akurasi pada tiga eksperimen. Pertama yakni akurasi model CNN pada eksperimen klasifikasi alfabet tercetak pada citra. Akurasi model CNN untuk keseluruhan alfabet diperoleh sebesar $98.97 \%$, dengan mayoritas alfabet dapat dikenali secara sempurna sebesar $100 \%$, namun terdapat beberapa kelas alfabet seperti huruf " $\mathrm{f}, \mathrm{i}, \mathrm{t}, \mathrm{v}$ ".

Kedua yakni akurasi klasifikasi teks (OCR) pada eksperimen klasifikasi kata pada citra teks. Model CNN digunakan untuk mengidentifikasi teks pada citra teks dengan tingkat akurasi klasifikasi teks (OCR) sebesar $50.72 \%$. Pada eksperimen ini masih banyak terjadi kesalahan klasifikasi. Kesalahan sering terjadi diakibatkan kegagalan dalam melakukan segmentasi objek khususnya untuk huruf i dan j. Karena dua huruf ini akan tersegmentasi menjadi 2 objek yang berbeda, yakni huruf i serta tanda titiknya.

Ketiga adalah akurasi terjemahan. Hasil identifikasi teks pada eksperimen kedua, akan digunakan untuk diterjemahkan dari teks Bahasa Indonesia ke Bahasa Daerah menggunakan algoritma Leveinstan Distance. Tingkat akurasi pada eksperimen ini 75.78\%. Algoritma Leveinstan Distance dapat meningkatkan performa terjemahan dengan memperbaiki kesalahan dalam proses identifikasi sebelumnya.

\section{Ucapan Terimakasih}

Terima kasih kepada Universitas Pembangunan Nasional Veteran Jakarta yang telah mendanai penelitian ini pada skema hibah internal Riset Dosen Pemula tahun 2021.

\section{Daftar Rujukan}

[1] KEMDIKBUD, "Bahasa dan Peta Bahasa di Indonesia," 2019. https://petabahasa.kemdikbud.go.id/ (accessed Nov. 08, 2021).

[2] National geographic, "How many of the world's languages are endangered National Geographic," 2018. https://www.nationalgeographic.co.uk/travel/2018/07/howmany-worlds-languages-are-endangered (accessed Nov. 10, 2021).

[3] Lindawati, "Bahasa Minangkabau Di Masa Depan Sebuah Proyeksi," in International Seminar on Language Maintenance and Shift (LAMAS) 7, 2017, pp. 348-352.

[4] P. Reza Amarta and K. Husnul, "Pola Pikir Penggunaan Bahasa Inggris Pada Masyarakat Perkotaan Di Jabodetabek," SIMULACRA | Pusat Studi Sosiologi dan Pengembangan Masyarakat, vol. 2, no. 1, pp. 39-52, 2018.

[5] M. Agus, S. Erlina, R. Farli, Wajiran, and B. Rohmat Indra, "Penerapan Convolutional Neural Network (CNN) pada Pengenalan Aksara Lampung Berbasis Optical Character Recognition (OCR)," Jurnal Edukasi dan Penelitian Informatika (JEPIN), vol. 7, no. 1, pp. 52-57, 2021.

[6] W. Antonius Kevin, S. Nanik, and K. Wijayanti Nurul, "Aplikasi Penerjemah Gambar Teks Berbahasa Inggris Menggunakan Teknologi Realitas Tertambah Pada Perangkat Berbasis Android," 2018.

[7] A. Ginting and A. Nazori, "Penerjemah Dua Arah Bahasa Indonesia Ke Bahasa Daerah (Karo) Menggunakan Teknik Statistical Machine Translation (Smt) Sebagai Fitur Pada Situs 
Web Untuk Meningkatkan Web Traffic,” Jurnal TELEMATIKA MKOM vol.4 no.1, Maret 2012.

[8] H. Sujaini, "Peningkatan Akurasi Penerjemah Bahasa Daerah dengan Optimasi Korpus Paralel," Jurnal Nasional Teknik Elektro dan Teknologi Informasi (JNTETI), vol. 7, no. 1, pp. 7-12, 2018.

[9] D. Soyusiawaty, "E-Translator With Rule Based IndonesiaMinang Dan Minang-Indonesia," Jurnal Informatika, vol. 2, no. 2, 2008, [Online]. Available: http://cimbuak.net.

[10]R. Darwis, H. Sujaini, R. Dwi Nyoto, "Peningkatan Mesin Penerjemah Statistik dengan Menambah Kuantitas Korpus Monolingual (Studi Kasus : Bahasa Indonesia-Sunda),”vol. 7, no. $1,2019$.

[11]U. Anisa Eka, N. Oky Dwi, and M. Kurniawan Teguh, "Aplikasi Penerjemah Bahasa Inggris - Indonesia dengan Optical Character Recognition Berbasis Android," Jurnal Teknologi dan Sistem Komputer, vol. 4, no. 1, pp. 167-177, 2016.

[12]Y. Jia et al., "Caffe: Convolutional architecture for fast feature embedding," in MM 2014 - Proceedings of the 2014 ACM Conference on Multimedia, Nov. 2014, pp. 675-678. doi: $10.1145 / 2647868.2654889$

[13]A. Naseer and K. Zafar, "Comparative Analysis of Raw Images and Meta Feature based Urdu OCR using CNN and LSTM," 2018. [Online]. Available: www.ijacsa.thesai.org

[14]M. R. Phangtriastu, J. Harefa, and D. F. Tanoto, "Comparison between Neural Network and Support Vector Machine in Optical Character Recognition," in Procedia Computer Science, 2017, vol. 116, pp. 351-357. doi: 10.1016/j.procs.2017.10.061.

[15] S. Srivastava, J. Priyadarshini, S. Gopal, S. Gupta, and H. S. Dayal, "Optical character recognition on bank cheques using 2D convolution neural network," in Advances in Intelligent Systems and Computing, vol. 697, Springer Verlag, 2019, pp. 589-596. doi: 10.1007/978-981-13-1822-1_55.

[16] A. Kumar Bhunia, A. Konwer, A. Kumar Bhunia, A. Bhowmick, P. P. Roy, and U. Pal, "Script Identification in Natural Scene Image and Video Frame using Attention based ConvolutionalLSTM Network."

[17]J. Wang, J. Qin, X. Xiang, Y. Tan, and N. Pan, "CAPTCHA recognition based on deep convolutional neural network," Mathematical Biosciences and Engineering, vol. 16, no. 5, pp. 5851-5861, 2019, doi: 10.3934/mbe.2019292.

[18]M. Mega Santoni, N. Chamidah, D. Sandya Prasvita, R. Amarta Prayoga, and B. Permana Sukma, "Penerjemahan Bahasa Indonesia ke Bahasa Minang dari Optical Character Recognition dengan Menggunakan Algoritme Edit Distance Translating Indonesian into Minang Languages from Optical Character Recognition Using the Edit Distance Algorithm," Jurnal Ilmu Komputer Agri-Informatika, vol. 7, no. 2, pp. 105-113, 2020, [Online]. Available: http://journal.ipb.ac.id/index.

[19]H. Md. Mosabbir, L. Md. Farhan, R. Ahmed Sady, D. Amit Kumar, and Monira Mukta, "Auto-correction of English to Bengali Transliteration System using Levenshtein Distance," International Conference on Smart Computing \& Communications (ICSCC), 2019.

20]W. Zar Zar, Th' eo Ducros, and A. Masayoshi, "Spell Corrector to Social Media Datasets inMessage Filtering Systems," 2017.

[21]M. Maulana Yulianto and R. Arifudin, "Autocomplete and Spell Checking Levenshtein Distance Algorithm to Getting Text Suggest Error Data Searching in Library," Scientific Journal of Informatics, vol. 5, no. 1, pp. 2407-7658, 2018, [Online]. Available: http://journal.unnes.ac.id/nju/index.php/sji

DOI: https://doi.org/10.29207/resti.v5i6.3614 